\title{
Direct effects of prolactin and dopamine on the gonadotroph response to $\mathrm{GnRH}$
}

\author{
Helen L Henderson, Julie Townsend and Domingo J Tortonese \\ Department of Anatomy, University of Bristol, Bristol BS2 8EJ, England, UK \\ (Correspondence should be addressed to D J Tortonese; Email: d.tortonese@bristol.ac.uk)
}

\begin{abstract}
The intrapituitary mechanisms underlying the inhibitory actions of hyperprolactinaemia on the reproductive axis remain unclear. Previous work on primary pituitary cultures revealed combined suppressive effects of prolactin (PRL) and dopamine on the gonadotrophin response to GnRH. However, whether these effects occur directly at the level of the gonadotroph and are accompanied by changes in gene expression is still unresolved. Here, $\alpha \mathrm{T}_{3}-1$ and $\mathrm{L} \beta \mathrm{T} 2$ cells were used to investigate the effects of PRL and dopamine on gonadotrophin synthesis and release in gonadotroph monocultures under basal and GnRH-stimulated conditions. PRL receptor and dopamine receptor mRNA expressions were first determined by RT-PCR in both cell lines. Then, PRL and the dopamine agonist bromocriptine $(\mathrm{Br})$, alone or in combination, were shown to

block the maximal $\alpha$-subunit and LH $\beta$-subunit mRNA responses to a dose-range of $\mathrm{GnRH}$. The $\mathrm{LH}$ secretory response was differentially affected by treatments. GnRH dose-dependently stimulated LH release, with a $4-5$ fold increase at $10^{-8} \mathrm{M}$ GnRH. Unexpectedly, PRL or Br stimulated basal LH release, with PRL, but not $\mathrm{Br}$, enhancing the $\mathrm{LH}$ secretory response to GnRH. This effect was, however, completely blocked by Br. These results reveal direct effects of PRL and dopamine at the level of the gonadotroph cell, and interactions between these two hormones in the regulation of gonadotrophin secretion. Moreover, uncoupling between $\mathrm{LH}$ synthesis and release in both the basal and the GnRH-stimulated responses to PRL and dopamine was clearly apparent.

Journal of Endocrinology (2008) 197, 343-350
\end{abstract}

\section{Introduction}

Hyperprolactinaemia is a major cause of amenorrhoea in humans and has been shown to be associated with the suppression of gonadotrophin secretion and impaired fertility in this (Delvoye et al. 1978, Kremer et al. 1991, Blackwell 1992) and other (Bartke et al. 1977, McNeilly et al. 1978) mammalian species. While the specific mechanisms underlying prolactin (PRL) effects on gonadotrophin release are still unresolved, it has become increasingly apparent that, in addition to the established actions of PRL at the level of the hypothalamus affecting gonadotrophin-releasing hormone $(\mathrm{GnRH})$ output, interactions between the gonadotrophic and PRL axes occur at the level of the pituitary gland. Indeed, close associations between gonadotrophs and lactotrophs were originally identified in the rodent pituitary, where cell-to-cell communication in the form of adherans junctions (Horvath et al. 1977) and specific gap junction coupling (Morand et al. 1996) could be established. These morphological associations between the gonadotroph and lactotroph cells have also been identified in the pituitaries of larger vertebrates, where isolated gonadotrophs were shown to be situated within clusters of lactotrophs (Tortonese et al. 1998, Gregory et al. 2000).

Functional observations further support the existence of intrapituitary effects of PRL on gonadotrophin secretion. PRL receptor mRNA and protein have been detected within the pituitary gland of the rat (Chiu et al. 1992), and treatment of cultured pituitary fragments with PRL resulted in the suppression of both basal and GnRH-stimulated luteinizing hormone (LH) release (Cheung 1983). In humans, the pituitary LH response to GnRH is reduced during lactational amenorrhoea when PRL concentrations are elevated (Jeppsson et al. 1974, Le Maire et al. 1974, Andreassen \& Tyson 1976), and this has been associated with LH pulses of low amplitude (Tyson et al. 1978, Glasier et al. 1984). Similarly, in subhuman primates, exogenous PRL was shown to suppress the LH response to GnRH (Maneckjee et al. 1976). An additional evidence for a direct pituitary action of PRL on the gonadotrophic axis was revealed by a study reporting the selective expression of PRL receptors in gonadotroph cells of the pars distalis and pars tuberalis of the ovine pituitary, a species that shows overt temporal changes in fertility throughout the year in response to photoperiod (Tortonese et al. 1998). More recently, our laboratory demonstrated a seasonal modulation of the combined suppressive effects of PRL and dopamine on the gonadotrophin response to GnRH (Gregory et al. 2004).

An immortalised gonadotroph cell line, $\alpha \mathrm{T}_{3}-1$, has been shown to express $D_{2}$-type dopamine receptors and it has been suggested that these receptors negatively regulate pituitary $\boldsymbol{\alpha}$-subunit gene expression in association with a 
cAMP-dependent pathway (Kanasaki et al. 2002), making it possible to investigate the direct effect of dopamine on a gonadotroph monoculture. $\alpha \mathrm{T}_{3}-1$ is a mouse-derived cell line which expresses the mouse gonadotrophin $\alpha$-subunit gene and synthesises and secretes the $\alpha$-subunit protein (Windle et al. 1990). These cells also express GnRH receptors within the concentration range observed in primary gonadotrophs, and activation of these receptors evoked an equivalent response to $\mathrm{GnRH}$ by increasing the $\boldsymbol{\alpha}$-subunit mRNA in a dose-dependent manner (Windle et al. 1990, Horn et al. 1991). As the $\alpha \mathrm{T}_{3}-1$ cell line was immortalised at a relatively early stage of development, it does not produce the gonadotrophin $\beta$-subunits. A similar cell line, L $\beta \mathrm{T} 2$, was created using tumorigenesis in transgenic mice carrying the LH $\beta$-subunit regulatory region (Alarid et al. 1996). These cells express the gonadotrophin $\alpha$-subunit, the LH $\beta$-subunit, $\mathrm{GnRH}$ receptor mRNA, and respond to $\mathrm{GnRH}$ with dosedependent increases in LH secretion, exhibiting functional characteristics consistent with those of normal pituitary gonadotrophs. Further studies have demonstrated $\mathrm{LH}$ secretion via a regulated pathway, and changes in $\mathrm{GnRH}$ receptor expression in response to signalling by $\mathrm{GnRH}$ and steroid hormones (Turgeon et al. 1996). As the L $\beta T 2$ cells represent $\alpha \mathrm{T}_{3}-1$ cells arrested at a later stage of development, it seems probable that the $\mathrm{L} \beta \mathrm{T} 2$ cell line will also express $\mathrm{D}_{2}$ dopamine receptors. The expression of PRL receptors by either of these cell lines is yet to be determined. If present, the $\alpha \mathrm{T}_{3}-1$ and/or L $\beta \mathrm{T} 2$ cell lines could offer a useful tool with which to investigate further the direct effects of PRL and dopamine on gonadotrophs.

The aim of this study was first to determine the expression of PRL receptors by $\alpha \mathrm{T}_{3}-1$ and L $\beta \mathrm{T} 2$ cell lines, as well as the expression of dopamine receptors by L $\beta \mathrm{T} 2$ cells. Subsequently, these cell lines were used to investigate the combined suppressive effects of PRL and dopamine by measuring the gonadotrophin $\alpha$-subunit and LH $\beta$-subunit mRNA responses to PRL and a dopamine agonist, alone or in combination, while simultaneously assessing the LH secretory response in the presence or absence of $\mathrm{GnRH}$.

\section{Materials and Methods}

\section{Cell culture and experimental design}

$\alpha \mathrm{T}_{3}-1$ and L $\beta \mathrm{T} 2$ gonadotroph cells (a gift from Dr Pamela Mellon, University of California, San Diego, CA, USA) were cultured in Dulbecco's modified Eagle's medium (DMEM; Gibco) containing 10\% fetal calf serum (PAA Laboratories, Linz, Austria) and $1 \%$ penicillin-streptomycin (Gibco), and maintained at $37{ }^{\circ} \mathrm{C}$ in an atmosphere of $95 \%$ air and $5 \% \mathrm{CO}_{2}$. The cells were plated onto six-well plates at $3 \times 10^{5}$ cells/well for 4 days, and then either treated for $24 \mathrm{~h}$ or washed in PBS (calcium-, magnesium- and sodium bicarbonate-free, Gibco) and incubated in serum-free DMEM overnight before treatment was applied for $90 \mathrm{~min}$. The cells were treated with: i) buffer (Control), ii) $\mathrm{GnRH}\left(10^{-7} \mathrm{M}\right)$, iii) bromocriptine (Br) $\left(10^{-8} \mathrm{M}\right)$, iv) PRL (500 ng/ml), v) GnRH+Br, vi) GnRH+ PRL and vii) GnRH+Br+PRL. The optimal GnRH dose required to generate a maximal mRNA response (i.e. $10^{-7} \mathrm{M}$ ) was previously determined by dose-response tests at $90 \mathrm{~min}$ and $24 \mathrm{~h}$. The doses of $\mathrm{Br}$ (a specific dopamine- $\mathrm{D}_{2}$ receptor agonist) and PRL employed in this study were selected on the basis of their previously observed effectiveness at inducing a biological response in preliminary studies, and in previous work in $\alpha \mathrm{T}_{3}-1$ (Kanasaki et al. 2002) and primary (Gregory et al. 2004) cultures. Following incubation, the medium was aspirated off prior to cell lysis and RNA extraction. GnRH and bromocriptine were purchased from Sigma-Aldridge Ltd, whereas PRL was obtained from Dr A F Parlow (ovine PRL, lot AFP-10692c, National Institute of Diabetes and Digestive and Kidney Diseases, NIDDKD, Torrance, CA, USA).

\section{RT-PCR}

Total RNA was extracted from $\alpha \mathrm{T}_{3}-1$ and $\mathrm{L} \beta \mathrm{T} 2$ cells, homogenised using QIAshredder columns (Qiagen) and purified using an RNeasy mini kit (Qiagen). mRNA was reverse-transcribed into single-stranded cDNA using oligo(dT)18 primer reverse transcriptase (Roche Diagnostics). cDNA samples were then subjected to PCR amplification using primers specific to: i) GAPDH, ii) a $645 \mathrm{bp}$ product common to the short and long forms of the PRL receptor, iii) the long form of the $\mathrm{D}_{2}$ dopamine receptor, iv) the gonadotrophin $\alpha$-subunit and v) the LH $\beta$-subunit (for sequences see Table 1). PCR amplification was carried out using a MJ research PTC-200 Peltier Thermal Cycler.

The conditions consisted of an initial denaturation step at $95^{\circ} \mathrm{C}$ for $2 \mathrm{~min}$, followed by an amplification step at temperatures appropriate for each primer set (see Table 1) for $45 \mathrm{~s}$, and extension at $72{ }^{\circ} \mathrm{C}$ for $1 \mathrm{~min}$. The optimal number of amplification cycles for quantification of the products of each primer set had been previously determined by titration experiments. These were 23 cycles for the $\alpha$-subunit and 25 cycles for the LH $\beta$-subunit expression. For the assessment of the expression of PRL and dopamine receptors, 35 cycles were used. Following amplification, the final $10 \mathrm{~min}$ extension step was carried out at $72{ }^{\circ} \mathrm{C}$. PCR products were separated by electrophoresis on a $1.5 \%$ agarose gel containing $0.1 \mu \mathrm{g} / \mathrm{ml}$ ethidium bromide and quantified by scanning densitometry using Bio-Rad Quantity One Quantification Software. The amounts of PCR products of each subunit were normalised to those of the PCR products of GAPDH in each sample and the values were converted to a percentage of the control in order to allow a direct comparison between individual experiments (Kanasaki et al. 2002).

\section{RIA}

The concentration of LH in culture medium following treatment was measured by RIA using reagents supplied by NIDDKD's National Hormone and Peptide Program and A F 
Table 1 Annealing temperatures and primer sequences used for PCR amplification of prolactin (PRL) receptor, $\mathrm{D}_{2}$ dopamine receptor and gonadotrophin $\alpha$ - and luteinizing hormone $\beta(\mathrm{LH} \beta)$-subunit genes

\section{Annealing temperature $\left({ }^{\circ} \mathrm{C}\right)$}

Gene

PRL-R ${ }^{\mathrm{a}}$

$\mathrm{D}_{2}$ Dopamine- $\mathrm{R}^{\mathrm{b}}$

$\alpha$-Subunit ${ }^{b}$

LH $\beta$-Subunit ${ }^{\mathrm{C}}$ 57
Sequence

\author{
5': GCA GAT GGA GGA CTT CCT ACC AAT TA \\ 3': GCA GGT CAC CAT GCT ATA GCC CTT \\ 5': AGA GCC AAC CTG AAG ACA CCA \\ 3': GAT GAT GAA CAC ACC GAG AAC \\ 5': ACT TTA TTA TTC AGG GGT TGC \\ $3^{\prime}$ : TAT AAG GGA TGT AAC CGT AAA \\ 5': TGG CTG CTG CTG AGC CCA AGT G \\ 3’: CAG GTC ATT GGT TGA GTC CTG G
}

aTortonese et al. (1998).

${ }^{\mathrm{b}}$ Kanasaki et al. (2002).

c Townsend (unpublished data).

Parlow, with all samples being assayed in duplicate in the same assay. The reference preparation employed was mouse $\mathrm{LH}$ (AFP-5306A), with rat LH (AFP-11536B) for iodination, and rat $\mathrm{LH}$ antiserum (NIDDK-anti-rLH-S-11) as the primary antibody. The minimum detectable concentration was $0 \cdot 1 \mathrm{ng} / \mathrm{ml}$ and the intra-assay coefficient of variation was $7 \cdot 2 \%$.

\section{Statistical analysis}

In both the $\alpha \mathrm{T}_{3}-1$ and L $\beta \mathrm{T} 2$ cultures, six doses of $\mathrm{GnRH}$ were employed for dose-response tests, while for treatment effects, seven experimental groups were used. For each group, four wells were assigned to each treatment, and the experiments were carried out three times with reproducible results. The values are expressed as means \pm s.E.M. The effects of treatments on the gonadotrophin subunit mRNA and secretory responses were examined by ANOVA, followed by pairwise comparison using Fisher's test to determine specific differences among treatments. Treatment effects were considered statistically significant at $P<0 \cdot 05$.

\section{$\alpha$ T3-1 gonadotrophs}
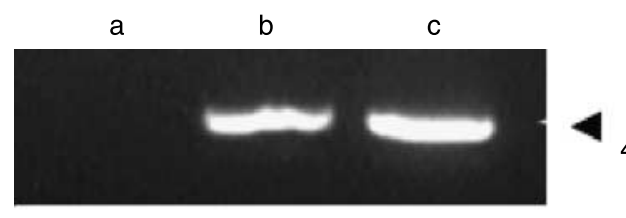

DA-R
$458 \mathrm{bp}$

\section{Results}

Expression of PRL and dopamine $D_{2}$ receptors in $\alpha T_{3}-1$ cells

In the first series of studies, total RNA from $\alpha T_{3}-1$ cells was analysed by RT-PCR to assess the presence of PRL receptors and confirm the expression of dopamine $\mathrm{D}_{2}$ receptors. As shown in Fig. 1, both the PRL receptor (645 bp) and the long form of the dopamine $\mathrm{D}_{2}$ receptor $(458 \mathrm{bp})$ mRNA were detected in $\alpha \mathrm{T}_{3}-1$ cells.

Effects of PRL and dopamine on $\mathrm{GnRH}$-induced $\alpha$-subunit gene expression in $\alpha T_{3-1}$ cells

Dose-response tests confirmed the ability of $\alpha \mathrm{T}_{3}-1$ gonadotroph cells to respond to GnRH under culture conditions. Acute $(90 \mathrm{~min})$ treatment resulted in a clear dose-dependent response, with a $2 \cdot 5$-fold increase in $\boldsymbol{\alpha}$-subunit mRNA at $10^{-7} \mathrm{M} \mathrm{GnRH}(P<0 \cdot 01$; Fig. 2A). In contrast, chronic $\mathrm{GnRH}$ treatment $(24 \mathrm{~h})$ showed a moderate increase at all
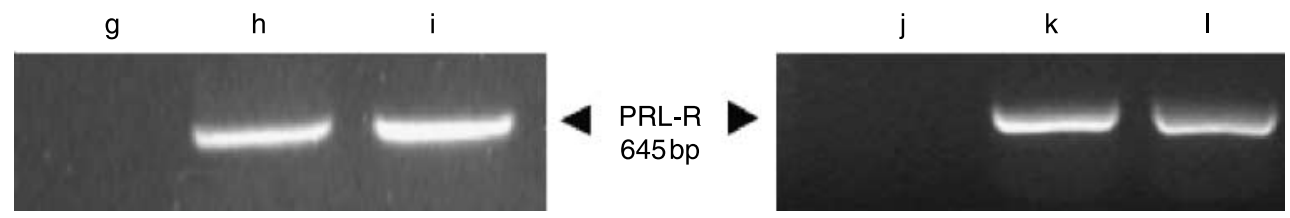

Figure 1 Assessment of the expression of $D_{2}$ dopamine receptor (DA-R) and PRL receptor (PRL-R) mRNA by $\alpha \mathrm{T}_{3}-1$ and L $\beta$ T 2 cells using RT-PCR. The products were separated on a $1 \cdot 5 \%$ agarose gel containing $0 \cdot 1 \mu \mathrm{g} / \mathrm{ml}$ ethidium bromide and quantified by scanning densitometry using Bio-Rad Quantity One software. Lanes b and $c, D_{2}$ dopamine receptor expression in $\alpha T_{3}-1$ cells; lanes e and $f, D_{2}$ dopamine receptor expression in $\mathrm{L} \beta \mathrm{T} 2$ cells; lanes $\mathrm{h}$ and $\mathrm{i}, \mathrm{PRL}$ receptor expression in $\alpha \mathrm{T}_{3}-1$ cells; lanes $k$ and I, PRL receptor expression in L $\beta$ T2 cells; lanes a, d, g and $j$, RT negative controls showing no mRNA expression. 

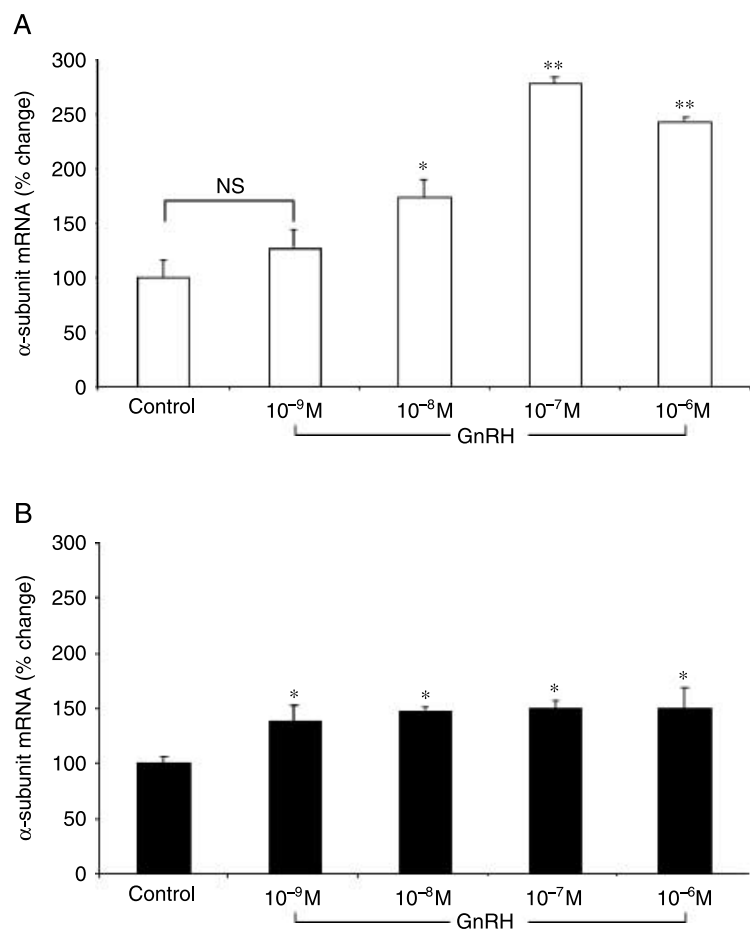

Figure 2 Effects of (A) acute (90 min) or (B) chronic (24 h) treatment of $\alpha \mathrm{T}_{3}-1$ cells with increasing doses of $\mathrm{GnRH}\left(10^{-9}-10^{-6} \mathrm{M}\right)$ on gonadotrophin $\alpha$-subunit mRNA expression. Values expressed as mean percentage of Control \pm S.E.M. $\left({ }^{*} P<0 \cdot 05,{ }^{* *} P<0 \cdot 01\right.$, relative to Control).

concentrations tested $(P<0 \cdot 05$; Fig. $2 \mathrm{~B})$. In the subsequent phase of this second series of studies, the acute application of PRL or Br did not modify basal $\alpha$-subunit mRNA expression (Fig. 3). However, the $\alpha$-subunit response to $\mathrm{GnRH}$ was totally suppressed when PRL or the dopamine agonist were applied alone or in combination $(P<0 \cdot 01)$. Similarly, in

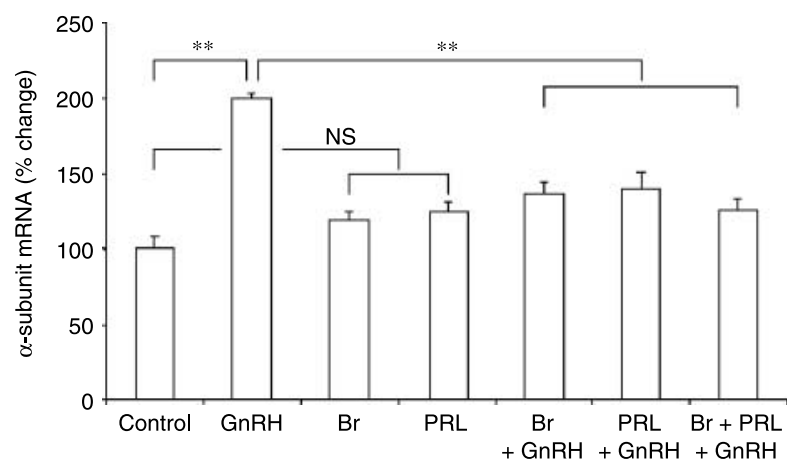

Figure 3 Gonadotrophin $\alpha$-subunit mRNA response in $\alpha T_{3}-1$ cultures following acute $(90 \mathrm{~min})$ treatment with: (i) buffer (Control), (ii) GnRH $\left(10^{-7} \mathrm{M}\right)$, (iii) bromocriptine ( $\left.\mathrm{Br}\right)\left(10^{-8} \mathrm{M}\right)$, (iv) $\mathrm{PRL}(500 \mathrm{ng} / \mathrm{ml}),(\mathrm{v}) \mathrm{GnRH}+\mathrm{Br}$, (vi) GnRH+PRL and (vii) GnRH+ $\mathrm{Br}+\mathrm{PRL}$. Values are expressed as a mean percentage of the Control \pm S.E.M. (NS, non-significant, ${ }^{* *} P<0 \cdot 01$ ). chronic (24 h) studies, a sub-maximal $\alpha$-subunit response to GnRH was observed after treatment with PRL or Br (data not shown).

Expression of $P R L$ and dopamine $D_{2}$ receptors in $L \beta T 2$ cells

In the third series of studies, total RNA from L $\beta T 2$ gonadotroph cells was analysed by RT-PCR to examine the expression of PRL and D2 dopamine receptors by this cell line. As shown in Fig. 1, both PRL receptor $(645 \mathrm{bp})$ and the long form of the dopamine $\mathrm{D}_{2}$ receptor $(458 \mathrm{bp}$ ) mRNA were detected in $\mathrm{L} \beta \mathrm{T} 2$ cells.

Effects of PRL and dopamine on GnRH-induced LH $\beta$-subunit gene expression in $L \beta T 2$ cells

In the fourth series of studies, L $\beta T 2$ cultures were treated acutely $(90 \mathrm{~min})$ with increasing doses of $\mathrm{GnRH}\left(10^{-9}\right.$ $\left.10^{-6} \mathrm{M}\right)$. A clear dose-response was observed, with maximal stimulation at $10^{-7} \mathrm{M}$ GnRH $(P<0 \cdot 01)$ (Fig. $\left.4 \mathrm{~A}\right)$. In the second phase of this series of studies, treatment with PRL or $\mathrm{Br}$, alone or in combination, completely suppressed the LHßsubunit mRNA response to GnRH $(P<0 \cdot 01)$ (Fig. 5A), whereas the same treatments had no effect on basal mRNA expression.
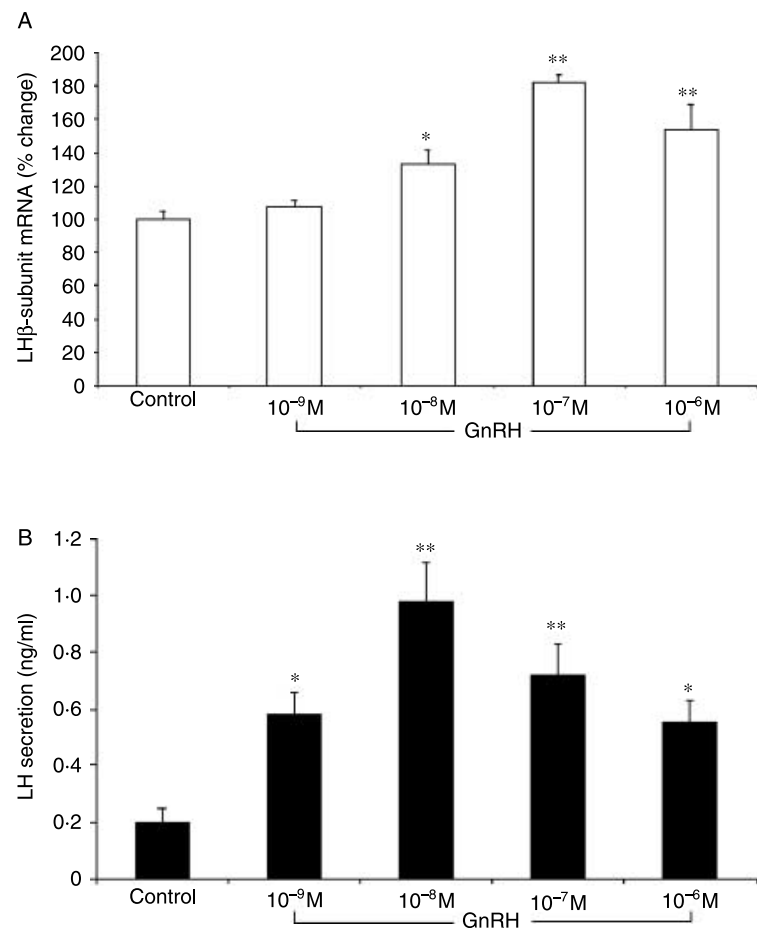

Figure 4 Effects of acute $(90 \mathrm{~min})$ treatment of L $\beta T 2$ cell cultures with increasing doses of $\mathrm{GnRH}\left(10^{-9}-10^{-6} \mathrm{M}\right)$ on $(\mathrm{A})$ expression of $\mathrm{LH} \beta$-subunit mRNA (values expressed as mean percentage of Control \pm S.E.M.) and (B) LH secretory response (as measured by RIA) $\left({ }^{* *} P<0 \cdot 01\right.$, relative to Control). 

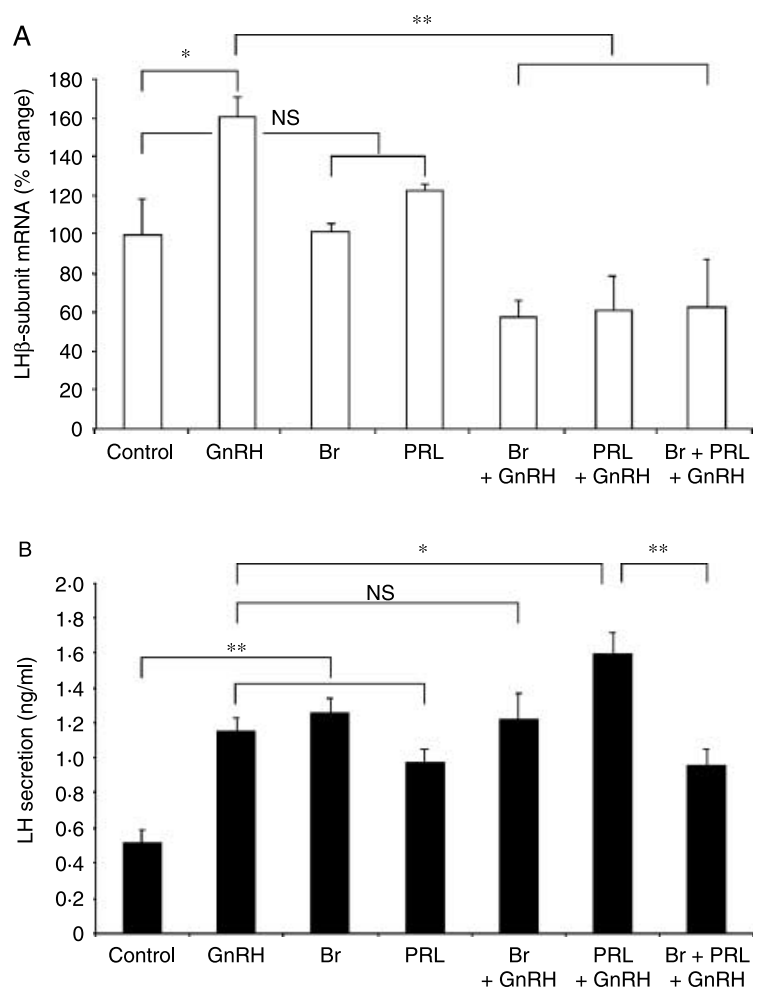

Figure 5 Expression of gonadotrophin $\mathrm{LH} \beta$-subunit mRNA (A), and $\mathrm{LH}$ secretory response (B), in L $\beta \mathrm{T} 2$ cell cultures following acute (90 min) treatment with (i) buffer (Control), (ii) $\mathrm{GnRH}\left(10^{-7} \mathrm{M}\right)$, (iii) bromocriptine $(\mathrm{Br})\left(10^{-8} \mathrm{M}\right)$, (iv) PRL $(500 \mathrm{ng} / \mathrm{ml})$, (v) GnRH+ $\mathrm{Br}$, (vi) $\mathrm{GnRH}+\mathrm{PRL}$ and (vii) $\mathrm{GnRH}+\mathrm{Br}+\mathrm{PRL}$. Values in (A) are expressed as a mean percentage of the Control \pm S.E.M. $\left({ }^{*} P<0 \cdot 05\right.$, $* * P<0 \cdot 01)$.

\section{Effects of PRL and dopamine on LH secretion in $L \beta T 2$ cells}

In the final series of studies, LH concentrations in the media from L $\beta$ T2 cultures were measured by RIA. GnRH stimulated LH release in a dose-dependent manner, with a fivefold increase at $10^{-8} \mathrm{M}$ GnRH $(P<0 \cdot 01)$ (Fig. 4B). While treatments with PRL or $\mathrm{Br}$ alone stimulated $\mathrm{LH}$ release $(P<0 \cdot 01), \mathrm{PRL}$, and not $\mathrm{Br}$, significantly enhanced the $\mathrm{LH}$ secretory response to $\mathrm{GnRH}(P<0 \cdot 05)$. Interestingly, this effect was completely suppressed by the simultaneous addition of the dopamine agonist $(P<0 \cdot 01)$ (Fig. 5B).

\section{Discussion}

The results of this study demonstrate the expression of functional PRL and dopamine receptors in gonadotroph cells. Indeed, suppression of the gonadotrophin mRNA response to $\mathrm{GnRH}$ at the level of both the $\alpha$ - and $\beta$-subunits by PRL and a dopamine agonist $(\mathrm{Br})$ was clearly apparent. Contrary to these observations, measurements of the LH secretory response in $\mathrm{L} \beta \mathrm{T} 2$ gonadotrophs revealed that single applications of PRL or Br were capable of stimulating basal LH secretion under these culture conditions. Moreover, the LH response to $\mathrm{GnRH}$ was enhanced by PRL, while the co-application of $\mathrm{Br}$ with $\mathrm{GnRH}$ did not alter the $\mathrm{LH}$ secretory response in comparison with the stimulation by $\mathrm{GnRH}$ alone. Interestingly, when PRL was combined with the dopamine agonist, the PRL-induced increase in the LH secretory response to GnRH was completely abolished.

While PRL is known to participate in the central control of fertility with well-documented effects in the hypothalamus, it is becoming increasingly apparent that PRL can also act directly at the level of the pituitary gland to regulate gonadotrophin output. Early morphological studies reporting intercellular interactions between gonadotroph and lactotroph cells in the rodent pituitary (Horvath et al. 1977) and the subsequent functional observations revealing hyperprolactinaemia-induced reduction of the $\mathrm{LH}$ secretory response to GnRH in rodents and humans (Cheung 1983) were subsequently supported by the identification of the two forms of the PRL receptor (gene and protein) within this tissue (Ouhit et al. 1993), thus confirming that the infrastructure required for a direct pituitary action of PRL is indeed present. In the current study, the demonstration that both the PRL receptor and the DA receptor are expressed within the gonadotroph has important clinical implications, since it reveals that the gonadotroph itself can be a point for the control of fertility in hyperprolactinaemia-induced amenorrhoea. Indeed, the suppression of both gonadotrophin subunits mRNA responses to GnRH by PRL and bromocriptine shows that the secretory effects of this treatment originally detected in primary cultures are likely to be accompanied by changes in gene expression.

The inhibition of the mRNA response to GnRH by PRL and $\mathrm{Br}$ (alone or in combination) may involve a cross-talk between the intracellular signalling pathways activated by GnRH and those activated by PRL and/or dopamine. The common components in the signalling of one or more of these hormones are likely to be mediating these interactions. GnRH receptors are members of the G-protein-coupled receptor family; ligand binding leads to the activation of $\mathrm{Gq}$ and/or G11 proteins (Shah \& Milligan 1994), stimulation of phospholipase C (PLC), production of diacylglycerol (DAG) and activation of various protein kinase $\mathrm{C}$ (PKC) isoforms (Harris et al. 1997). Downstream of this pathway, GnRH activates the extracellularly regulated kinase (ERK) cascade of the mitogen-activated protein kinase (MAPK) signalling pathway via a PKC and tyrosine kinase-dependent mechanism (Naor et al. 2000). Simultaneously, GnRH induces intracellular calcium mobilisation and extracellular calcium influx (Stojilkovic et al. 1994). PRL receptors are members of the cytokine family (Kelly et al. 1993) and are coupled to Janus Kinase 2, a tyrosine kinase. The activation of these receptors leads to phosphorylation, and thus activation of specific transcription factors from the signal transducer and activator of transcription (Stat) protein family (Ihle 1996). The PRL receptor has also been implicated in the stimulation of MAPK cascades (Piccoletti et al. 1997), and connections 
between the JAK-Stat and MAPK pathways have been suggested (Bole-Feysot et al. 1998). Dopamine receptors, like GnRH receptors, are G-protein-coupled; these receptors are linked to $\mathrm{G}_{\alpha} 0$ and/or $\mathrm{G}_{\alpha \mathrm{I}}$ proteins (Enjalbert et al. 1988). The activation of the dopamine receptor results in an immediate increase in intracellular potassium and a consequent reduction in the intracellular free calcium, leading to an inhibition of release from secretory granules (Gregerson 2001). Additionally, dopamine acts to suppress PLC, thus reducing calcium release from the endoplasmic reticulum (Caccavelli et al. 1992). The principal pathway responsible for reduced gene transcription following activation of the dopamine receptor results in the inhibition of adenylyl cyclase (Taussig \& Gilman 1995), decrease in cAMP production and suppression of activated PKA (Diamond et al. 1999).

The dopamine and GnRH receptors therefore share many components involved in signal transduction. While GnRH activates PLC (Huckle \& Conn 1987), dopamine is known to have an inhibitory action, thus preventing the generation of inositol 1, 4, 5-triphosphate (IP3) and DAG (Vallar et al. 1988) and opposing the GnRH-induced increases in intracellular calcium concentration and PKC and MAPK activities (Levi et al. 1998). Interestingly, MAPK activity has been suggested as a mediator of GnRH-induced stimulation of gonadotrophin subunit gene transcription (Roberson et al. 1995). Consequently, by preventing the activation of PKC and inhibiting the increase in MAPK activity, dopamine may be able to decrease gonadotrophin subunit gene transcription. Conversely, the suggestion that PRL may also be involved in the activation of MAPK signalling cascades (Piccoletti et al. 1997), leads to the possibility that overactivation of MAPK may underlie the observed inhibition of the gonadotrophin mRNA response to GnRH by PRL through a decrease in the cytoplasmic pool of ERK for subsequent phosphorylation. Therefore, the ERK/MAPK cascade may represent the common signalling pathway mediating the suppressive effects of dopamine and PRL on the gonadotrophin subunit mRNA response to the secretagogue.

The results of this study demonstrate an uncoupling between gonadotrophin synthesis and release in response to treatments, with the LH secretory response to GnRH not being inhibited by PRL or $\mathrm{Br}$; in fact, PRL alone resulted in an enhancement of this response. Because the activation of calcium mobilisation associated with gonadotrophin release could run in parallel to, and to some extent be independent of, the activation of the ERK/MAPK pathway, the augmentation of the $\mathrm{LH}$ response to $\mathrm{GnRH}$ induced by PRL may result from the up-regulation of other signalling components. Indeed, we have recently observed that the stimulatory action of PRL on LH release is PKC-dependent (Hodson et al. 2008). Given that GnRH activates PKC, and that the activation of this enzyme increases the affinity of intracellular calcium for hormone exocytosis (Zhu et al. 2002), it is likely that PRL-induced activation of PKC accounts for the observed enhancement the LH secretory response to GnRH. Overall, the present findings are consistent with those of an early study in post-partum women where the $\mathrm{LH}$ response to exogenous $\mathrm{GnRH}$ was suppressed during the first month after parturition but enhanced above follicular phase levels in the second month (Keye \& Jaffe 1976). In the case of dopamine, the blockade of the PRL-induced enhancement of the secretory response to $\mathrm{GnRH}$ by the co-application of bromocriptine is an important observation, which corroborates previous findings in primary cultures (Gregory et al. 2004). If PRL is indeed inducing the observed enhancement through up-regulation of certain signalling components, dopamine is likely to be blocking these effects.

It thus becomes apparent that the paradoxical effects of PRL (i.e. whether stimulatory or inhibitory) on LH synthesis and release are likely to be dependent on the dopaminergic tone within the tissue. This may explain the apparent discrepancies in the reported associations between PRL and gonadotrophin secretion during lactational amenorrhoea in humans. Specifically, whereas some studies have provided evidence for a negative correlation between gonadotrophin secretion and PRL at this time (Jeppsson et al. 1974, Le Maire et al. 1974, Andreassen \& Tyson 1976, Delvoye et al. 1978, Duchen \& McNeilly 1980) and that the duration of puerperal amenorrhoea is positively associated with the level of prolactinaemia (Diaz et al. 1989, 1991), others have found no correlation between the two (Nunley et al. 1991, Tay et al. 1992). In a study where dopamine and opioid antagonists were administered to breastfeeding women, the resulting increases in endogenous PRL secretion did not significantly affect the gonadotrophin responses to an injection of $\mathrm{GnRH}$ (Tay et al. 1993). Since in the present study the LH secretory response to the secretagogue was enhanced by PRL, and that effect was unambiguously blocked by DA, it would be thus pertinent to consider what mechanisms could develop in vivo in some circumstances to counteract the suppressive effects of hyperprolactinaemia on the reproductive axis reported by others and/or the robust treatment effects observed here in vitro.

In conclusion, this study has demonstrated the expression of functional PRL and dopamine receptors by gonadotroph cells. These receptors were shown to mediate the suppressive effects of PRL and a dopamine agonist on the gonadotrophin mRNA response to GnRH, not only at the level of the common $\alpha$-subunit but also affecting the LH $\beta$-subunit. In contrast, the LH secretory response to $\mathrm{GnRH}$ was augmented by PRL. While the dopamine agonist did not share this ability, it was able to block the enhancing effect of PRL when the two were co-applied. These results have important clinical implications since they provide evidence for uncoupling between gonadotrophin synthesis and release in response to treatments; they also support previous observations in primary cultures revealing that the combined suppressive effects of PRL and dopamine on the gonadotrophin response to $\mathrm{GnRH}$ are accompanied by alterations in gonadotrophin subunit mRNA expression. 


\section{Acknowledgements}

We would like to thank Dr Pamela Mellon (University of California, San Diego, CA, USA) for the generous gift of $\alpha \mathrm{T}_{3}-1$ and $\mathrm{L} \beta \mathrm{T} 2$ cell lines, the NIDDKD's National Hormone \& Peptide Program and Dr A F Parlow (HarborUCLA Medical Center, Torrance, CA, USA) for providing RIA reagents and biologically active PRL and David Hodson (University of Bristol, UK) for critical reading of the manuscript. These studies were financially supported by the Department of Anatomy, University of Bristol, and the BBSRC. The authors declare that there is no conflict of interest that would prejudice the impartiality of this scientific work.

\section{References}

Alarid ET, Windle JJ, Whyte DB \& Mellon PL 1996 Immortalization of pituitary cells at discrete stages of development by direct oncogenesis in transgenic mice. Development 122 3319-3329.

Andreassen B \& Tyson JE 1976 Role of the hypothalamic-pituitary-ovarian axis in puerperal infertility. Journal of Clinical Endocrinology and Metabolism 42 1114-1122.

Bartke A, Smith MS, Michael SD, Peron FG \& Dalterio S 1977 Effects of experimentally-induced chronic hyperprolactinaemia on testosterone and gonadotropin levels in male rats and mice. Endocrinology 100 182-186.

Blackwell RE 1992 Hyperprolactinemia: evaluation and management. Endocrinology and Metabolism Clinics of North America 21 105-124.

Bole-Feysot C, Goffin V, Edery M, Binart N \& Kelly PA 1998 Prolactin (PRL), and its receptor: actions, signal transduction pathways and phenotypes observed in PRL receptor knockout mice. Endocrine Reviews 19 225-268.

Caccavelli L, Cussac D, Pellegrini I, Audinot V, Jaquet P \& Enjalbert A 1992 D2 dopaminergic receptors: normal and abnormal transduction mechanisms. Hormone Research 38 78-83.

Cheung CY 1983 Prolactin suppresses luteinizing hormone secretion and pituitary responsiveness to luteinizing hormone-releasing hormone by a direct action at the anterior pituitary. Endocrinology 113 632-638.

Chiu S, Koos RD \& Wise PM 1992 Detection of prolactin receptor (PRL-R) mRNA in the rat hypothalamus and pituitary gland. Endocrinology 130 1747-1749.

Delvoye P, Badawi M, Demaegd M \& Robyn C 1978 Serum prolactin, gonadotrophins and estradiol in menstruating and amenorrhoeic women during two years of lactation. American Journal of Obstetrics and Gynaecology $130635-640$.

Diamond SE, Chiono M \& Gutierrez-Hartmann A 1999 Reconstitution of the protein kinase A response of the rat prolactin promoter: differential effects of distinct Pit-1 isoforms and functional interaction with Oct-1. Molecular Endocrinology 13 228-238.

Diaz S, Seron-Ferre M, Cardenas H, Schiapacasse V, Brandeis A \& Croxatto HB 1989 Circadian variation of basal plasma prolactin, prolactin response to suckling, and length of amenorrhoea in nursing women. Journal of Clinical Endocrinology and Metabolism 68 945-955.

Diaz S, Cardenas H, Brandeis A, Miranda P, Schiapacasse V, Salvatierra AM, Herreros C, Seron-Ferre M \& Croxatto HB 1991 Early differences in the endocrine profile of long and short lactational amenorrhoea. Journal of Clinical Endocrinology and Metabolism 72 195-201.

Duchen MR \& McNeilly AS 1980 Hyperprolactinaemia and long-term lactational amenorrhoea. Clinical Endocrinology 12 621-627.

Enjalbert A, Musset F, Chenard C, Priam M, Kordon C \& Heisler S 1988 Dopamine inhibits prolactin secretion stimulated by the calcium channel agonist Bay-K-8644 through a pertussis toxin-sensitive $\mathrm{G}$ protein in anterior pituitary cells. Endocrinology 123 406-412.

Glasier A, McNeilly AS \& Howie PW 1984 Pulsatile secretion of LH in relation to the resumption of ovarian activity post partum. Clinical Endocrinology 20 415-426.
Gregerson KA 2001 Mechanism of dopamine action on the lactotroph. In Prolactin, pp 45-61. Ed. ND Horseman. Boston: Kluwer.

Gregory SJ, Brooks J, McNeilly AS, Ingleton PM \& Tortonese DJ 2000 Gonadotroph-lactotroph associations and expression of prolactin receptors in the equine pituitary gland throughout the seasonal reproductive cycle. Journal of Reproduction and Fertility 119 223-231.

Gregory SJ, Townsend J, McNeilly AS \& Tortonese DJ 2004 Effects of prolactin on the luteinizing hormone response to gonadotropin-releasing hormone in primary pituitary cell cultures during the ovine annual reproductive cycle. Biology of Reproduction 70 1299-1505.

Harris D, Reiss N \& Naor Z 1997 Differential activation of protein kinase C delta and epsilon gene expression by gonadotrophin-releasing hormone in alphaT $\mathrm{T}_{3}-1$ cells. Journal of Biological Chemistry 272 13534-13540.

Hodson DJ, Townsend J \& Tortonese DJ 2008 Prolactin induces luteinizing hormone release from gonadotroph cells in a JAK2-PI3K-PKC-dependent manner. 85th Annual Meeting of the Endocrine Society, San Diego, CA, USA.

Horn F, Bilezikjian LM, Perrin MH, Bosma MM, Windle JJ, Huber KS, Blount AL, Hille B, Vale W \& Mellon PL 1991 Intracellular responses to gonadotropin-releasing hormone in a clonal cell line of the gonadotrope lineage. Molecular Endocrinology 5 347-355.

Horvath E, Kovacs K \& Ezrin C 1977 Functional contacts between lactotrophs and gonadotrophs in the rat pituitary. IRCS Medical Science 5511.

Huckle WR \& Conn PM 1987 The relationship between gonadotrophinreleasing hormone-stimulated luteinizing hormone release and inositol phosphate production: studies with clacium antagonists and protein kinase C activators. Endocrinology 120 160-169.

Ihle J 1996 STATs: signal transducers and activators of transcription. Cell $\mathbf{8 4}$ 331-334.

Jeppsson S, Rannevik G \& Kullander S 1974 Studies on the decreased gonadotropin response after administration of LH-FSH-releasing hormone during pregnancy and the puerperium. American Journal of Obstetrics and Gynaecology 120 1029-1034.

Kanasaki H, Yonehara T, Yamada Y, Takakashi K, Hata K, Fujiwaki R, Yamamoto H, Takeuchi Y, Fukunaga K \& Miyamoto E 2002 Regulation of gonadotropin $\alpha$ subunit gene expression by dopamine $\mathrm{D}_{2}$ receptor agonist in clonal mouse gonadotroph $\alpha \mathrm{T}_{3}-1$ cells. Biology of Reproduction 67 1218-1224.

Kelly PA, Ali S, Rozaki SM, Goujon L, Nagano M, Pellegrini I, Gould D, Djiane J, Edery M, Finidori J et al. 1993 The growth hormone/prolactin receptor family. Recent Progress in Hormone Research 48 123-164.

Keye WRJ \& Jaffe RB 1976 Changing patterns of FSH and $\mathrm{LH}$ response to gonadotropin-releasing hormone in the puerperium. Journal of Clinical Endocrinology and Metabolism 42 1133-1138.

Kremer JA, Borm G, Schellekens LA, Thomas CM \& Rolland R 1991 Pulsatile secretion of luteinizing hormone and prolactin in lactating and nonlactating women and the response to naltrexone. Journal of Clinical Endocrinology and Metabolism 72 294-300.

Levi NL, Hanoch T, Bernard O, Rozenblat M, Harris D, Reiss N, Naor Z \& Seger R 1998 Stimulation of Jun N-terminal kinase (JNK) by gonadotrophin-releasing hormone in pituitary alpha $\mathrm{T}_{3}-1$ cell line is mediated by protein kinase C, c-Src, and CDC42. Molecular Endocrinology 12 107-122.

Le Maire WJ, Shapiro AG, Riggall F \& Yang NS 1974 Temporary pituitary insensitivity to stimulation by synthetic LRF during the postpartum period. Journal of Clinical Endocrinology and Metabolism 38 916-918.

Maneckjee R, Srinath BR \& Moudgal NR 1976 Prolactin suppresses release of luteinizing hormone during lactation in the monkey. Nature 262 507-508.

McNeilly AS, Sharpe RM, Davidson DW \& Fraser HM 1978 Inhibition of gonadotrophin secretion by induced hyperprolactinaemia in the male rat. Journal of Endocrinology 79 59-68.

Morand I, Fonlupt P, Guerruer A, Trouillas J, Calle A, Remy A, Rousset B \& Munari-Silem Y 1996 Cell-to-cell communication in the anterior pituitary: evidence for gap junction-mediated exchange between endocrine cells and folliculostellate cells. Endocrinology 137 3356-3367.

Naor Z, Bernard O \& Seger R 2000 Activation of MAPK cascades by G-protein-coupled receptors: the case of gonadotrophin-releasing hormone receptor. Trends in Endocrinology and Metabolism 11 91-99. 
Nunley WC, Urban RJ \& Evans WS 1991 Preservation of pulsatile luteinizing hormone release during postpartum lactational amenorrhoea. Journal of Clinical Endocrinology and Metabolism 73 629-634.

Ouhit A, Morel G \& Kelly PA 1993 Visualization of gene expression of short and long forms of prolactin receptor in the rat. Endocrinology 133 135-144.

Piccoletti R, Bendinelli P \& Maroni P 1997 Signalling transduction pathway of prolactin in rat liver. Molecular and Cellular Endocrinology 135 169-177.

Roberson MS, Misra-Press A, Laurence ME, Stork PJ \& Maurer RA 1995 A role for mitogen-activated protein kinase in mediating activation of the glycoprotein hormone alpha-subunit promoter by gonadotropin-releasing hormone. Molecular and Cellular Biochemistry 15 3531-3539.

Shah B \& Milligan G 1994 The gonadotrophin-releasing hormone receptor of $\alpha \mathrm{T}_{3}-1$ pituitary cells regulates cellular levels of both the phosphoinositidase C-linked G proteins, Gq alpha and G11 $\alpha$, equally. Molecular Pharmacology 46 $1-7$.

Stojilkovic SS, Tomic M, Kukuljan M \& Catt KJ 1994 Control of calcium spiking frequency in pituitary gonadotrophs by a single-pool cytoplasmic oscillator. Molecular Pharmacology 45 1013-1021.

Taussig R \& Gilman AG 1995 Mammalian membrane-bound adenylyl cyclases. Journal of Biological Chemistry 270 1-4.

Tay CCK, Glasier AF \& McNeilly AS 1992 The 24 h pattern of pulsatile luteinizing hormone, follicle stimulating hormone and prolactin release during the first eight weeks of lactational amenorrhoea in breastfeeding women. Human Reproduction 7 951-958.

Tay CCK, Glasier AF \& McNeilly AS 1993 Effect of antagonists of dopamine and opiates on the basal and GnRH-induced secretion of luteinizing hormone, follicle stimulating hormone and prolactin during lactational amenorrhoea in breastfeeding women. Human Reproduction $8532-539$
Tortonese DJ, Brooks J, Ingleton PM \& McNeilly AS 1998 Detection of prolactin receptor gene expression in the sheep pituitary gland and visualisation of the specific translation of the signal in gonadotrophs. Endocrinology 139 5215-5223.

Turgeon JL, Kimura Y, Waring DW \& Mellon PL 1996 Steroid and pulsatile gonadotropin-releasing hormone $(\mathrm{GnRH})$ regulation of luteinizing hormone and GnRH receptor in a novel gonadotrope cell line. Molecular Endocrinology 10 439-450.

Tyson JE, Carter JN, Andreassen B, Huth J \& Smith B 1978 Nursingmediated prolactin and luteinizing hormone secretion during puerperal lactation. Fertility and Sterility 30 154-162.

Vallar L, Vincentini LM \& Meldolesi J 1988 Inhibition of inositol phosphate production is a late, $\mathrm{Ca}^{2+}$-dependent effect of D2 dopaminergic receptor activation in rat lactotroph cells. Journal of Biological Chemistry 264 10127-10134.

Windle JJ, Weiner RI \& Mellon PL 1990 Cell lines of the pituitary gonadotrope lineage derived by targeted oncogenesis in transgenic mice. Molecular Endocrinology 4 597-603.

Zhu H, Hille B \& Xu T 2002 Sensitization of regulated exocytosis by protein kinase C. PNAS 99 17055-17059.

Received in final form 12 February 2008

Accepted 21 February 2008

Made available online as an Accepted Preprint

21 February 2008 